doi: 10.15503.jecs2021.2.455.468

Journal of Education Culture and Society No. 2_2021

\title{
LITERARY REALISM IN THE SHAPING OF SLOVAK CULTURE
}

\author{
MILAN KENDRA \\ Institute of Slovak and Media Studies, Faculty of Arts, University of Prešov \\ ul. 17. novembra 1, 08001 Prešov, Slovakia \\ E-mail address: milan.kendra@unipo.sk \\ ORCID: https://orcid.org/0000-0001-6200-630X
}

\begin{abstract}
Aim. The aim of the study is to clarify the internal complexity of the Slovak literary realist discourse and its diverse relations to the heterogeneous artistic, cultural and ideological discourses of the last third of the $19^{\text {th }}$ century. The emphasis is placed on the appropriation and adaptation of stimuli from other social systems, as well as on the specific literary operations that modify literary realism as an artistic discourse constructing an intelligible world in a cultural sense.

Methods. As a theoretical concept, realism is defined as a type of representation or representation technique associated with a set of textual conventions, complex referential and self-referential figures. As a literary-historical discourse and event situated in a particular moment of history, realism is governed by period-specific cultural operations and related principles of selecting, evaluating and connecting the phenomena forming the horizon of reality. Only with this dichotomy, the multiplicity of paradoxes, syncretism and heterogeneous character of Slovak literary realism can be captured. The theory of social systems (Luhmann, 1995, 2000) allows for a more complex view of realist literature as an autopoietic system in the context of modern society, which itself is viewed as a system of communications differentiated into a network of separate social subsystems interrelated by the medium of language. Finally, the theory of fictional worlds proposes selective and formative operations that explicate the construction of the realist fictional world and the stratification of its functions (Fořt, 2014).
\end{abstract}

Results and conclusion. Among the configurational relations of Slovak literary realism, the concept of ideal realism is highlighted as a model of literary aesthetics that flexibly interacted with the discourse of national revival to provide an adequate expression of contemporary Slovak cultural and national interests. Two literary aesthetic modifications of ideal realism (creative and voluntarist, developed by Svetozár Hurban Vajanský, and deterministic, represented in the prose works of Martin Kukučín) are analysed in detail in order to show the inner complexity of the literary realist discourse and to manifest its semantic multidimensionality in the 1880s.

Key words: literary realism, representation, referentiality, realist fictional world, social systems, autopoietic system, national revival, ideal realism 


\section{INTRODUCTION}

Tn the last two decades, Slovak literary historiography has reconsidered the Itheoretical and methodological foundations of research on literary realism in order to explain the differences in the expressive qualities and structures of literary texts of the last third of the $19^{\text {th }}$ century, which are in Slovak culture generally regarded as realist. Previous interpretations did not take into account the contradictions and specificities of individual authorial poetics and did not provide sufficient analytical means to describe semantic and axiological principles in Slovak realist narrative fiction. Conceptions of Slovak literary realism as a coherent poetics, a global style type, or as a linear and compact period of literary history proved unsustainable. Instead, a more methodologically appropriate and plausible explanation has been introduced that approaches realism as a complex, multidimensional, and pluralistic event in which a number of heterogeneous discourses occur. In this context, the configurational relations of the discourse of literary realism have been shaped, modified, and adapted to the norms of social consensus, as well as anthropological and ideological expectations.

As a theoretical concept, realist literary discourse is regarded as a type of representation linked to concrete referential and self-referential textual figures that create the reality effect. As a communicative convention, it is associated with mimesis as recognition because it requires the creative conscious activity of the reader in order to establish meaningful relationships between events and actions and to construct an intelligible world from a realist narrative. Moreover, as a literary-historical category, it is governed by the logic of the positive method and by the period-specific principles of selecting, expressing and connecting phenomena of reality formulated in the system of causality. With regard to this constructive aspect, the research does not address the question of how realism as a literary discourse imitates or repeats an already existing reality but focuses on how the reality effect of realist fiction is produced semiotically, how realist referential figures construct and shape reality in a cultural sense, and how they correspond to historical cultural and ideological discourses. The discourse of literary realism can be considered an autopoietic system that uses its system-specific operations to communicate, adapts its internal complexity, and co-evolves with other psychic and social systems. The functionally differentiated system of realist literature must be seen in the context of the functionally differentiated modern society of the second half of the $19^{\text {th }}$ century.

\section{ON CONTEMPORARY RESEARCH OF SLOVAK LITERARY REALISM}

There has been a systematic effort in contemporary Slovak studies to stimulate and continue the discussion on literary realism and its interplay with the aesthetic codes of romanticism, late romanticism, naturalism and modernism represented in Slovak literature of the late $19^{\text {th }}$ century. The ini- 
tiative was motivated by the need to reformulate the issue and to challenge the previous interpretation of realism based mainly on ideological criteria. Typological differences of literary texts, diversity of stylistic features and linguistic means among the oeuvres of the most significant representatives of this period (Pavol Országh Hviezdoslav, Svetozár Hurban Vajanský, Martin Kukučín, Elena Maróthy-Šoltésová, Terézia Vansová, Božena SlančíkováTimrava, Jozef Gregor Tajovský, Janko Jesenský) were addressed only formally, through the application of appropriate labels (ideal realism, critical realism, psychological realism, optimistic and pessimistic realism). This led to a monolithic interpretation of Slovak literary realism, unifying the horizons of diverse individual artistic programmes and overlooking different sources of the paradigms of Slovak realist writing. Even the most representative publications from the second half of the $20^{\text {th }}$ century show how difficult it was to provide a methodologically appropriate and plausible explanation of realism that would incorporate the individual authorial poetics into the concept of a global style type or literary method of the period. One of the most inspiring contributions is provided by Oskár Čepan (1984, pp. 17-45), who developed a very complex interpretive method to account for the contradictions in the axiology and poetics of Slovak realist prose and to explain a wide range of semantic principles employed. Although Čepan accepted the concept of Slovak literary realism as a coherent system from the late $19^{\text {th }}$ century to 1918, his analyses proved that the components of literary realism coincided with elements of other poetics as well as with facts of a non-literary nature. Čepan's work thus anticipated further direction of research focusing on realism as a heterogeneous, non-linear, multidimensional, pluralistic event that openly confronts the ideologically preferred conception of panrealism typical of the previous period.

The aim of the current approach is to interpret Slovak literature of the late $19^{\text {th }}$ century and the turn of the $20^{\text {th }}$ century anew in the light of its culturalhistorical situation, in which radical and deliberate transformations of discourses could be observed. The event of Slovak literary realism is presented "as a configuration of several heterogeneous artistic, cultural and ideological discourses, within which the discourse of artistic realism is reshaped, modified and adapted as a result of diverse relations" (Taranenková, 2016, p. 36). As far as the theoretical delineation of this research is concerned, literary realist discourse is seen as a type of representation associated with a set of textual conventions. The intrinsic characteristics, topoi, tropes, and composition of individual works of art are examined because literary theory understands realism "no longer as a reflection of reality but as a discourse that has its rules and conventions, like a code that is neither more natural nor truer than others" (Compagnon, 2004, p. 77). Given the semiotic nature of representation, referentiality and self-referentiality, representation is understood as a convention in which both author and reader participate, and the horizon of research shifts from "How does literature copy the real?" into "How does it make us believe that it copies the real?". 
Having linked realist literary discourse to concrete referential and selfreferential textual figures of speech, it was necessary to rethink its connection to knowledge, the world, and reality. According to Gerald M. Edelman (2005), consciousness and representation are closely related; the conscious process involves representation, which can be considered as one of the steps towards the expansion of higher-order consciousness. Higher-order consciousness allows the recognition by a thinking subject of his or her own acts and affections, and is accompanied by the ability to recreate past episodes and to form future intentions. Peter Zajac (2011, p. 15) understands referentiality and self-referentiality as different ways of representing consciousness that are associated with specific signs and rhetorical figures. The notion of realism in this context presupposes referentiality and corresponding, usually very complex, referential figures. Mimesis is no longer an imitation, the production of copies or repetition of the already existing real; on the contrary, it is an active operation, a creative activity constructing and giving meaning to the story and leading to recognition and interpretation. It is rehabilitated as a particular form of knowledge of the human world and presents itself as "a cognitive activity taking form from the experience of time, configuration, synthesis, dynamic praxis, which, instead of imitating, produces what it represents, augments common meaning, and issues in recognition" (Compagnon, 2004, p. 96). At this stage Zajac (2011, p. 14) pointed to the issue of narrative, which is inseparable from recognition because narrative composition affords intelligibility of events as well as an apprenticeship to give meaning to human actions; narrative "is our way of living in the world - of living the world - it represents our practical knowledge of the world and involves the communal work of construction of an intelligible world" (Compagnon, 2004, pp. 95-96).

In literary theory, the concept of realism as a type of representation is closely associated with producing the reality effect, with mimesis as the recognition by which the reader learns, concludes and establishes intelligible relationships between the elements of the plot. However, this is not enough to define this term as a literary-historical discourse. For realism as an event in the history of literature, additional criteria must be considered and added that reflect historical knowledge of the general rules and the laws that (should) control the intellect. The principles of selecting, expressing and connecting the phenomena of reality were formulated at that time in the system of causality and the logic of the positive method:

In the final, the positive state, the mind has given over the vain search after Absolute notions, the origin and destination of the universe, and the coituses of phenomena, and applies itself to the study of their laws, - that is, their invariable relations of succession and resemblance. Reasoning and observation, duly combined, are the means of this knowledge (Comte, 2000, p. 28).

The exploration of the invariable relations of succession and resemblance became the methodological guideline and working hypothesis of the prose 
writers of Slovak realism in the late $19^{\text {th }}$ century and are, therefore, an essential part of the characterisation of realism as a literary-historical discourse.

In order to encompass the relations between different historical-cultural discourses, but also the connections between various entities in the structure of individual texts, current research on literary realism in Slovak studies is oriented towards distinguishing its configurations. In these configurations, the coexistence of interacting elements originating from poetics, literary history or ideology has been identified. Ivana Taranenková (2016) also acknowledges their subsequent modification and re-contextualisation, as well as the appropriation and adaptation of stimuli from other (mainly Slavic) literatures, and the elimination of tendencies (Parnassianism, naturalism, modernism) actively present in Western European literature of the period. Among the configurational relations of Slovak literary realism, one should highlight in particular: the relations to the process of national revival (and the concept of ideal realism as its continuation); the adoption of elements of the Slavic cultural type (from Czech and Russian culture); the confrontation with naturalism perceived as a product of culture with a negative sign of anticulture (Lotman \& Uspensky, 1978, p. 220); and the selective adoption and modification of the aesthetic innovations of modernism.

Current research on Slovak literary realism, reinterpreting literary texts of this period in the Slovak literary canon, is based on the synoptic-pulsational modelling of literary history, a concept developed in Slovak studies by Zajac $(1993,2006,2009)$. In this context, some publications that point to the complexity of realist literary discourse should be mentioned, for example, Marcela Mikulová, who places the fiction of Božena Slančíková-Timrava between realism and modernism and explains how this Slovak woman writer transcends the realist analogy of representation and reality (1993); overcomes the distorted and simplistic interpretations of Jozef Gregor Tajovskýs prose exposed to ideological abuse in the previous period and presents him as a fin de siècle writer inspired by the ideas of national revival and modernist tendencies (2005); or, in a series of analytical studies, captures the multiple paradoxes, syncretism and heterogeneous character of Slovak literary realism in the works of its most prominent authors (2010). The theoretical and methodological foundations of research on literary realism are discussed (for more detail, see Mikulová \& Taranenková, 2011). Finally, there are publications that rely on the fundamental concepts of structural semiotics and aesthetics of communication and analyse the potential of realist fiction for the production of meaning and meaningful communication. The ways of modelling the characteristic clusters of the thematic (composition) and linguistic (stylisation) components of realist fiction are elucidated (Kendra, 2013, 2017). The aesthetic programme of literary realism is also examined in coincidence with modernist tendencies (Mitka, 2017). 


\section{FUNCTIONS OF REALIST FICTION IN THE SHAPING OF SLOVAK CULTURE}

The referential signs, textual conventions and rhetorical figures of realist fiction should be related to the criterion of the probable, not in the natural sense (eikos, the possible), but in the cultural sense (doxa, opinion). The probable of realist fictional worlds is thus constituted semiotically, emerging through the interplay of multiple semiotic systems and conforming to the code and norms of social consensus. Their reference is focused on culture, ideology and common opinion and is derived from "a system of conventions and anthropological or sociological expectations" (Compagnon, 2004, p. 76). The further part of this paper focuses on how the category of the real signified in realist fiction corresponds to cultural and ideological discourses of the 19th-century Slovak culture.

Realism as a literary-historical discourse situated in a particular moment of history is governed by period-specific principles of selecting, expressing and evaluating the phenomena of reality. The description of realism needs to be distinguished from other period concepts, which is why René Wellek considers it as a regulative concept, "a system of norms dominating a specific time, whose rise and eventual decline it would be possible to trace and which we can set clearly apart from the norms of the periods that precede and follow it" (1976, p. 225). Wellek is aware of inevitable contradictions - realist fiction, encompassing didacticism, moralism, social reformism, and criticism, is at once prescriptive and instructive; its objective method does not mean the suppression or absence of the author; realism arrives at a social type and shows a new historical sense of the mechanistic and deterministic interpretation of nature introduced by science, a world of cause and effect, but it also creates worlds of imagination. In the semantics of possible worlds, a bidirectional exchange between fiction and actuality is proposed, because "in one direction, in constructing fictional worlds, the poetic imagination works with 'material' drawn from actuality; in the opposite direction, fictional constructs deeply influence our imaging and understanding of reality" (Doležel, 1998, p. x). The world of literary realism can be regarded as a natural fictional world organised by selection (of constituents) and formative operations (generating stories) in order to create "worlds where nothing exists and nothing happens that would violate the laws of the actual world" (Doležel, 1998, p. 115).

The exchange of information between the actual and the fictional allows for a more complex view of (realist) literature in the context of modern society as a system of communications differentiated into a network of separate social subsystems interrelated by the medium of language. By distinguishing between consciousness (psychic systems, authors and readers), literature (as a social system) and other social systems (politics, economics, ethics, science, law), it can be assumed that literature is an autopoietic system (Luhmann, 1995, 2000) that uses its system-specific operations and selectivity in order to cope with the complexity of its environment. Systems that observe themselves and each 
other interrelate and co-evolve by adapting their system-specific complexities and responding to the changing conditions of their environment through self-referential operations within their own boundaries.

This explains not only Slovak realism as a configuration of multiple heterogeneous discourses but also the complexity of its referential rhetoric strategies and textual figures - the functionally differentiated system of realist literature emerged together with functionally differentiated modern society of the second half of the $19^{\text {th }}$ century. For this reason, this study further explores the selectivity of Slovak realist literature and its internal complexity in order to elucidate how it historically participated in communication with other social systems and achieved cultural legitimacy.

After the Austro-Hungarian Compromise of 1867, the literary field in Slovak culture was in a confluence of different communication systems as a result of circumstances that affected the Slovak reality in Upper Hungary (the northern part of the Kingdom of Hungary). The political idea of a one-nation Hungarian state was enforced and harsh Magyarisation measures were introduced. The Hungarian nation had to be uniquely Magyar, which meant "that it had to be united by use of the Magyar language in all administration, literature and education" (Kováč, 2011, p. 125). Not only were Slovak linguistic and cultural demands not accepted (as of a non-Magyar nationality), but on the contrary, Slovaks were deprived of the last cultural institutions that had been established as a result of limited reforms in 1860s. Matica slovenská (the national representative institution) was eradicated and the activities of the three existing Slovak grammar schools were suppressed. In the following decades, representatives of the Slovak intelligentsia managed to formulate several alternative conceptions of national development in order to achieve the goals of the Slovak political programme. In the context of the emerging Slovak national culture with the recently codified Slovak literary (written) language (1843, reformed and stabilised in 1851), literary realism had to interact flexibly with the discourse of national revival. Literary discourse not only had to deal with the aesthetics of realism, but also had to provide the adequate expression of the concepts that dominated the intellectual debate of the time: cooperation between Slavic nations (the cultural unity of Slavs), currents of Pan-Slavism, the national liberation struggle of the southern Slavs, the idea of Slavic (specifically Czech and Slovak) cultural and literary reciprocity, political messianism, the preservation of the attributes of national identity, etc.

As a result, Slovak literary realism evaluated and specifically modified elements that appeared in other discourses and social systems (including conceptions of national and historical ideology, Slavic patriotism, Magyarisation, political, legal, or educational discourse, and journalism). This brought a great stratification of the functions that literary discourse was supposed to fulfil. According to Yuri M. Lotman and Boris A. Uspensky (1978, p. 216), if the text was not reality but the material for its reconstruction, it would be important for realist literary discourse to establish rules according to which members of the cultural group were to reconstruct reality from the literary text consistent 
with ideas of Slovak national development. This would contribute to the inner unification of the Slovak cultural model. Slovak realist discourse was supposed to spread a cultural code with a strong regulating and unifying influence. Accordingly, Slovak culture of the last third of the $19^{\text {th }}$ century exhibits features of a model "chiefly oriented towards content and represented as a system of rules" (Lotman \& Uspensky, 1978, p. 219), and these rules, which determined the creation of texts, were set by the national defence ideology of the Slovak national movement. In the Slovak context, the concept of ideal realism emerged as a model of literary aesthetics and a cultural intermediary serving to explain the tension between the proclaimed ideal and its limited presence in empirical reality (Taranenková, 2014, p. 137).

In such a situation, the theme of Slovak realist fiction did not refer to the real situation in Slovak society but was an expression of ideologically based principles operating in the mechanism of culture. As soon as literary texts were composed following this generative mechanism, they were recognised as significant and began to serve as texts and rules of Slovak national activity. From the 1880s onwards, Slovak realist literature as a subsystem of national culture concentrated its modelling potential on the sphere within its own borders, with the aim of preserving, not expanding, this type of culture. Contemporary literary criticism and literary discourse, therefore, strongly opposed the tendencies which did not correspond with the normative discourse, according to which Slovak culture constituted a separate cultural type, antithetical to the West. On the other hand, closer links were forged with other non-Magyar nations of the Kingdom of Hungary, especially with the Czech literary and artistic life in the sense of cultural and political cooperation of all Slavic nations.

Under these circumstances, the re-presenting function of textual figures and conventions in Slovak realist literature of the 1880s forms a background for ideological content, its semantic layers and imagery. Empirical phenomena were evaluated and filtered by an ideologically determined axiological principle. The objectifying function (expected of literary realism) was replaced by the pragmatic function of fiction, highlighted at the time as "a medium that was efficient in spreading nationalistic thought, as was its participating role in the formation of Slovak national life" (Taranenková, 2014, pp. 135-136). Ideas of the Slovak national movement subsequently underwent a process of objectification through the motifs of objective reality. This is the reason why a significant shift in the composition of the sub-functions of the realist evocative function (Fořt, 2014) can be observed. Realist discourse in Slovak literature with its claim of direct penetration into life and reality had its didactic, moralistic, rhetorical, idyllic, and prescriptive implications, which were subordinated to epistemological and educational functions. These, however, were severely limited. The dissemination of ideas of the Slovak national consciousness and the goals of national revival broke the important link between realist discourse and objective social observation. Literary visions presenting the ideals that would revive national life were not covered by descriptive and analytical methods that would lead to knowledge of the objective order 
of reality. The concept of ideal realism in the context of $19^{\text {th }}$ century Slovak literature thus accentuated the tension between description and prescription, observation and instruction, and made its contradictory nature even more visible.

\section{VAJANSKÝ AND KUKUČÍN - TWO MAJOR MODELS OF LITERARY REALISM IN SLOVAK CULTURE IN $1880 \mathrm{~S}$}

The concept of ideal realism as a model of literary aesthetics, which was closely related to the ideology of the Slovak national movement, acquired several modifications in the Slovak literature of the 1880s. Authors not only had to find an alternative to the anachronistic poetic devices of romanticism but also to link literary discourse with concepts of national development and to respond to different cultural stimuli coming from other national literatures. One of these was Comte's positivist axiom of identity and causality of qualitatively identical phenomena of reality. This concept was gradually valorised and utilised in the poetics of individual authors, and to varying degrees, they incorporated it into the creative semantic principles of their fiction. Therefore, the focus is on two divergent aesthetic programmes that emerged in the given social, historical and cultural circumstances of the time. The first, creative and voluntarist, was developed in the extensive work of Svetozár Hurban Vajanský (1847-1916); the second, deterministic, was in turn represented in the prose works of Martin Kukučin (1860-1928). These authors are considered the founders of two paradigmatic lines of Slovak prose that go beyond the $20^{\text {th }}$ century (Taranenková, 2014).

In the Slovak cultural and realist literary discourse of the last third of the $19^{\text {th }}$ century, Vajanský as an aesthete, prose writer, poet, journalist, publicist, editor and publisher embodied the leading position. Vajanský, a creator and promoter of the historical and defensive ideology of the Slovak national movement (especially after the electoral defeat of the Slovak National Party in 1881) expressed his views on a wide range of political, cultural and economic issues. Vajanský's fiction, criticism and journalism bear traces of interdiscursive communication, and his literary-aesthetic conception in particular can be understood as interdiscourse. His model of Slovak realist writing was thus largely anchored in the coordinates of the Slovak national movement, which was to pursue the development of literature and intellectual abilities (Hollý, 2010, p. 37). The political programme of the Slovak national movement was limited as a result of the Dual Pact between Germany and Austria-Hungary (1879), followed by the centralisation and Magyarisation policy of the Kingdom of Hungary. Although the programme could not be implemented, the repression did not directly hinder Slovak cultural development and literary life. The demand for the development of adequate Slovak literature became an integral part of the Slovak national movement (which could participate only to a limited extent in public affairs). In adverse conditions, the cultivation of 
literature was a means of preserving the attributes of national identity, language, customs and an expression of national consciousness. In his early cultural essay "Literary activity" (1879), Vajanský expressed his conviction that literature would become the source of a new intellectual life. In a series of articles, "Critical letters" (1880), a literary-aesthetic conception was presented, which combined the classical aesthetic ideal with the demand for national literature as a pragmatic response to the contemporary situation in culture and politics. Vajanský called for a Slovak/Slavic theme of art which should provide observation and self-description of the national society and its struggles. The fiction was meant to represent the renewal of the national organism, as well as the forces that threaten it (e.g. alienation from national life). In this context, the fundamental opposition between the "own" and the "foreign" was formulated as the defining axiological principle of Vajanský's fiction, which is why his literary model of reality is marked by the voluntary creation of a substitutionary fictional society. Vajanskýs social and moral thought, didacticism and allegorisation served the immediate goal of recognising the situation of the Slovak intellectual elite, which had assumed the role of representative of the mass of the nation. Vajanský fiction provided a reduced vision of Slovak national society caused by individually evaluated and depicted reality. Therefore, it is not surprising that Vajansky's model of the realist world is paradoxically characterised as creative voluntarism (Čepan, 1984). In recent research, the means of melodramatic imagination in Vajanský's fiction have been recognised (Taranenková, 2014).

The normative model of Vajanský's realist fiction stemmed from his stratification of the Slovak community into the mass of the nation (the people) and the national intelligentsia (the representatives). While the mass can only perform the function of preserving nationality, the role of its intellectual elite is to represent the nation. In a later series of articles, "Moods and views" (1897), Vajanský explained that the essence or substance of Slovak identity (nationality) was maintained in an unchanged state by the mass of the nation as biologically (biosocially) and ethnographically (ethnosocially) defined individuality. The mass did not develop a conscious nationality for itself, so the basic duty of the representatives was to give form and expression to national existence, to give nationality a visible and artistic shape. Literature and literary life, stimulated by the intellectual elite, were to develop Slovak consciousness, which was already latent among the masses. This was why Vajanský, in his essay "Art and nationality" (1882), highly appreciated genres such as the novella or the novel, which were able to influence reality with their suggestive power: "But a good novella, a good novel [...], bursts with real life, and is capable of founding a new spiritual colony in the desert of our impoverished life" (Vajanský, 2008b, p. 324).

Alongside Vajanskýs literary-aesthetic conception, in which literature was a mediator of national consciousness as well as proof of the great national achievements of the Slovak intelligentsia, Kukučín's literary model focused on the minute description of manners, events, details and typical circum- 
stances that gave an expression of the national individuality and uniqueness of the mass of the nation. If Vajanský was concerned with the national consciousness of his contemporary social intellectual elite, Kukučín concentrated on the literary analysis of the Slovak microcosm and its elementary existence. With the scope and detail of the themes of his literary works, Kukučín created an artistic image of the Slovaks as a fully developed national unit (its content became everyday judgments about the facts of life, practical life argumentation and its rhetoric, general opinion, traditional life of the Slovak ethnic group, norms, rules and customs of the village community). Compared to Vajanský, Kukučín minimised the influence of the ideological function and modified the evocative functions in favour of personal, local, temporal, epistemological, cultural, and contextual sub-functions (for more detail, see Fořt, 2014). Kukučín developed the possibilities of the descriptive realist short story with its documentary, informative and narrative potential. This was followed by changes concerning the internal structure of the narrative, in particular the relationship between the discourse of the narrator and the discourse of the characters. In the context of Kukučín's short prose, several types of techniques for rendering consciousness of literary characters, such as psycho-narration (Cohn, 1978), can be identified. Although Kukučín's realist method of writing produced more convincing solutions and results than Vajanský's (Taranenková, 2014), he did not avoid interaction with the ideal when constructing a plausible fictional world. The fact that he tried to transfer the norms of life, the linguistic forms and the way of folk thinking into the composition of a literary work did not automatically mean neglecting the ideal. Kukučín developed an objective and deterministic formula of epic harmony governing the relations between man, the social environment, tradition and nature (Čepan, 1984). Although this formula was seemingly consistent with the positivist axiom of causality, succession and resemblance, it did not help the writer to fulfil the assumption of impersonality, the suppression of any interference by the author. On the contrary, the formula of epic harmony represents the ideal of organic relationships by which the implied author "instructs us silently, through the design of the whole" (Chatman, 1978, p. 148) that beyond the boundaries of his literary world, there is an unacceptable restlessness, disharmony, and chaos of contradictory interests. The simulated objectivity in the formula of epic harmony was Kukučín's favourite semantic principle with which he masked his doubts about life, his sadness and inner anxiety that traditional and archaic values (as a guarantee of the individuality of the Slovak community) would not last in the modern world. The formula of epic harmony is characteristic of a distinctive authorial subject who intervenes and disrupts the impression of reality because he wants to restore and stabilise the unity of man and his collective consciousness with dynamic social, political and economic relations. The contradictory nature of Kukučin's realist fictional world is due to the fact that its author "endeavoured to solve the issues of life harmonically, but eventually was forced to accept the incongruous reality" (Mikulová, 2010, p. 247). 


\section{CONCLUSION}

The discourse of Slovak literary realism participated flexibly and closely in communication exchanges with the Slovak national movement, especially with the discourse of national revival, which sought to find an adequate expression of Slovak cultural and national interests. For this reason, configurations of heterogeneous discourses and different elements can be distinguished in the internal complexity of Slovak literary realism. This also explains the great stratification of the functions that Slovak literary discourse was supposed to fulfil. As a representative of the national movement, it contributed to the internal unification of Slovak culture. The concept of ideal realism emerged as a model of literary aesthetics that related referential textual figures with an image of reality filtered according to ideological principles. The objectifying function of realist discourse was replaced by a pragmatic function with the intention to determine the audience's respective perception of reality. However, the didactic, moralistic, rhetorical, idyllic, and prescriptive aspects of the realist evocation were limited because the link between realist discourse and objective social observation was severed.

The concept of ideal realism acquired several modifications in the context of Slovak literature in the 1880s. In the creative and voluntarist aesthetic programme of Svetozár Hurban Vajanský (1847-1916), literature was a mediator of national consciousness as well as a proof of the great national achievements of the Slovak intelligentsia. The literary-aesthetic conception of Martin Kukučín (1860-1928) developed differently from Vajanský's, whose fictional stories were to provide a self-description of national society and its struggles, as well as to represent the ideal of the renewal of the national organism. Kukučín's realist artistic model was based on the process of selecting the constituents of his fictional world and focused on the minute description of manners, events, details and typical circumstances that gave an expression of the national individuality and uniqueness of the mass of the nation. His formula of epic harmony represented the ideal of organic relationships in order to restore and stabilise the unity of man and his collective consciousness with dynamic social, political and economic relations. These modifications of the ideal realism not only manifest the semantic multidimensionality of Slovak literary realist discourse in the 1880s, but also prove that the themes of Slovak realist fiction did not refer to historical reality or the real situation in Slovak society, but were an expression of ideologically based principles operating in the mechanism of culture. It is important to note this in order to avoid distorted and simplistic interpretations of the aesthetic code of literary realism in the communication between literature and other social systems.

\section{AKNOWLEDGEMENT}

The study is published under the grant APVV-18-0043 Dictionary of Slovak Literary Works after 1989. 


\section{REFERENCES}

[1] Cohn, D. (1978). Transparent minds. Narrative modes for presenting consciousness in fiction. Princeton: Princeton University Press.

[2] Compagnon, A. (2004). Literature, theory, and common sense. Princeton: Princeton University Press.

[3] Comte, A. (2000). The positive philosophy of Auguste Comte. Kitchener: Batoche Books.

[4] Čepan, O. (1984). Stimuly realismu [The stimuli of realism]. Bratislava: Tatran. Retrieved May 24, 2021, from https://monoskop.org/images/c/c4/Cepan_Oskar_Stimuly_realismu.pdf.

[5] Doležel, L. (1998). Heterocosmica. Fiction and possible worlds. Baltimore and London: John Hopkins University Press.

[6] Edelman, G. M. (2005). Wider than the sky: The phenomenal gift of consciousness. New Haven: Yale University Press.

[7] Fořt, B. (2014). Fikční světy české realistické prózy [Fictional worlds of Czech realist prose]. Praha: Akropolis.

[8] Hollý, K. (2010). The negation of event history and historical optimism: The historical ideology of Svetozár Hurban Vajanský (1881 - 1897). Historický časopis, 58(Supplement), 23-52. Retrieved May 21, 2021, from http://www.historickycasopis.sk/pdf/HCsupplement2010.pdf.

[9] Chatman, S. (1978). Story and discourse. Narrative structure in fiction and film. Ithaca, New York: Cornell University Press.

[10] Kendra, M. (2013). Kontúry slovenskej prózy obdobia realismu [Contours of Slovak fiction of the period of realism]. Prešov: Filozofická fakulta Prešovskej univerzity v Prešove.

[11] Kendra, M. (2017). Korelácie témy a jazyka v slovenskom literárnom realisme [Correlation of theme and language in Slovak literary realism]. Prešov: Filozofická fakulta Prešovskej univerzity v Prešove.

[12] Kováč, D. (2011). The Slovak political programme: from Hungarian patriotism to Czecho-Slovak state. In M. Teich, D. Kováč \& M. D. Brown, Slovakia in history (pp. 120-136). New York: Cambridge University Press.

[13] Lotman, Yu. M., \& Uspensky, B. A. (1978). On the semiotic mechanism of culture. New Literary History, 9(2), 211-232.

[14] Luhmann, N. (1995). Social systems. Stanford: Stanford University Press.

[15] Luhmann, N. (2000). Art as a social system. Stanford: Stanford University Press.

[16] Mikulová, M. (1993). Próza Timravy medzi realismom a modernou [The fiction of Timrava between realism and modernism]. Bratislava: Ústav slovenskej literatúry SAV.

[17] Mikulová, M. (2005). Tajovského obrodenecká moderna [Tajovský's national revivalist modernism]. Bratislava: Kalligram a Ústav slovenskej literatúry.

[18] Mikulová, M. (2010). Paradoxy realismu [Paradoxes of realism]. Bratislava: VEDA, vydavatel'stvo Slovenskej akadémie vied.

[19] Mikulová, M., \& Taranenková I. (Eds.). (2011). Reálna podoba realismu [The real form of realism]. Bratislava: Ústav slovenskej literatúry SAV. Retrieved May 21, 2021 from https:// www.academia.edu/5015421/Realna_podoba_realismu_zbornik.

[20] Mitka, M. (2017). Stredoeurópska próza moderny [Central European prose of the modern period]. Prešov: Prešovská univerzita v Prešove. Retrieved May 24, 2021 from https:/ / www. pulib.sk/web/pdf/web/viewer.html?file=/web/kniznica/elpub/dokument/Mitka1/ subor/9788055518893.pdf.

[21] Taranenková, I. (2014). Towards an adequate storyworld and expression: Description in Slovak realist fiction. In A. Jedličková (Ed.), On description (pp. 134-153). Praha: Nakladatelství Akropolis. Retrieved May 20, 2021, from http://www.ucl.cas.cz/edicee/images/data/ sborniky/2014/opaj/10.pdf.

[22] Taranenková, I. (2016). Konfigurácie slovenského literárneho realismu [Configurations of Slovak literary realism]. In M. Mikulová \& I. Taranenková (Eds.), Konfigurácie slovenského realismu [Configurations of Slovak realism] (pp. 27-71). Brno: Host - vydavatelství, s. r. o.

[23] Vajanský, S. H. (1979a). Literárna činnost' [Literary activity]. In I. Kusý (Ed.), Slovenská literárna kritika 2 [Slovak literary criticism 2] (p. 154). Bratislava: Slovenský spisovatel.

[24] Vajanský, S. H. (1979b). Kritické listy [Critical letters]. In I. Kusý (Ed.), Slovenská literárna kritika 2 [Slovak literary criticism 2] (pp. 173-180). Bratislava: Slovenský spisovatel'. 
[25] Vajanský, S. H. (2008a). Nálady a výhl'ady [Moods and views]. In I. Taranenková (Ed.), Svetozár Hurban Vajanský. Koreň a výhonky. Články [Svetozár Hurban Vajanský. Root and shoots. Articles] (pp. 363-399). Bratislava: Kalligram a Ústav slovenskej literatúry SAV.

[26] Vajanský, S. H. (2008b). Umenie a národnost' [Art and nationality]. In I. Taranenková (Ed.), Svetozár Hurban Vajanský. Koreň a výhonky. Články [Svetozár Hurban Vajanský. Root and shoots. Articles] (pp. 320-324). Bratislava: Kalligram a Ústav slovenskej literatúry SAV.

[27] Wellek, R. (1976). Concepts of criticism. New Haven and London: Yale University Press.

[28] Zajac, P. (1993). Existuje čosi ako pulzačné dejiny literatúry? [Does anything like pulsating history of literature exist?]. Slovenská Literatúra, 40(6), 417-424.

[29] Zajac, P. (2006). Literárne dejepisectvo ako synoptická mapa [Literary historiography as synoptic map]. In D. Tureček \& Z. Urválková (Eds.), Medzi texty a metodami. Národní a univerzální $v$ české literatuř 19. století [Between texts and approaches. The national and universal aspects in the Czech literature of the $19^{\text {th }}$ century] (pp. 13-22). Olomouc: Periplum.

[30] Zajac, P. (2009). Národná stredoeurópska literatúra ako súčast' stredoeurópskej kultúrnej pamäti [National Central European literature as part of Central European cultural memory]. In D. Tureček (Ed.), Národní literatura a komparatistika [National literature and comparative studies] (pp. 33-47). Brno: Host - vydavatelství, s. r. o.

[31] Zajac, P. (2011). Reprezentácia, referencialita, realismus [Representation, referentiality, realism]. In M. Mikulová \& I. Taranenková (Eds.), Reálna podoba realismu [The real form of realism] (pp. 11-22). Bratislava: Ústav slovenskej literatúry SAV. 